\title{
EVALUATION OF LABNEH MADE FROM COWS' MILK AND GOATS' MILK USING PROBIOTIC AND EXOPOLYSACCHARIDE - PRODUCING BACTERIA
}

\author{
A. M. T. Gabr \\ Department of dairy research, Food Technology Research Institute (FTRI), Agric. Res. Centre, \\ Ministry of, Agric., Giza, Egypt
}

Received: Mar. 16, 2016

Accepted: May 25,2016

\begin{abstract}
Many lactic acid bacteria strains can biosynthesis exopolysaccharides (EPS) that are added to many types of food to enhance their rheological properties, the aim of this work was to manufacture low fat Labneh using mixture of cows and goats' milk with EPS producing probiotic starter. This starter consisted of Streptococcus thermophilus TA061, MR$1 C+$ Lactobacillus delbrueckii subsp. bulgaricus MR-1R+ Bifidobacterium bifidum and Lactobacillus acidophilus. The results indicated that the use of these bacteria increased the yield, total solids and fat in dry matter of Labneh prepared from mixture of cow and goat's milk containing $1 \%$ fat (CG1). The experimental Labneh was ranked higher scoring points compared with Labneh made from goat's milk 3\% fat $(G)$ and made with the use of traditional starter.
\end{abstract}

Key words: Mixtures of cow's milk and goat's milk, Labneh, probiotic, organoleptic properties, exopolysaccharides lactic acid bacteria.

\section{INTRODUCTION}

The world production of goat's milk is in a continuous increase. According to the Food and Agriculture Organization (FAO), goat's milk production reached approximately 12,8 MT in 2008 (FAO, 2011), There is a growing demand for goat's milk by consumers mainly due to the increasing number of children suffering from cow's milk allergy. Goat's milk and its products have been characterized by higher digestibility and certain nutritional and therapeutic effects in human nutrition (Haenlein, 2004). Although goat's milk has a higher fat content of strong smelling than cow and buffalo's milk (Park et al., 2007) the good production and handling of goat's milk yield milk indistinguishable in taste and odor from cow's milk.

Labneh (concentrated yoghurt), is a semi solid fermented dairy food produced by removing part of the whey from yoghurt until the total solids level reaches between 23 and $25 \%$, of which $8-11 \%$ is fat (Tamime and Robinson, 1999). The homogenization of traditional and UF Labneh made from goat and sheep's milk produced a smoother texture, but markedly decreased the firmness compared with Labneh made from cow's milk. In addition, goat and sheep's Labneh had similar microstructure but less uniform than Labneh made from cow's milk (Tamime et al., 1991). Recently, it could be avoid the goaty flavour, e.g. using adding aromatic oils (Abou ayana and Gamal El deen, 2011) and/ or might be mix two or three types of milk.

An alternative class of bio-thickeners is the microbial exopolysaccharides (EPS). Microbial exopolysaccharides are extracellular polysaccharides that are either associated with the cell surface in the form of capsules or secreted into the extracellular environment in the form of slime. They are referred to as capsular or slime exopolysaccharides, respectively. EPS occur widely among bacteria and microalgae and less among yeasts and fungi (Sutherland, 1972 and Sutherland, 1990). 
EPS-producing LAB increased the yield and improved the rheological properties of low-fat yoghurt and texture profile of kareish cheese (Abou Ayana and Ibrahim, 2015).

The aim of this study was to improve the quality of Labneh made from mixtures of cow's and goat's milk by using EPSproducing bacteria strains ( $S$. thermophilus TA061, MR-1C, and L. delbrueckii subsp. bulgaricus MR-1R) and probiotic strains of $B$. bifidum and $L$. acidophilus.

\section{MATERIALS AND METHODS}

Milk: Fresh cow and goat's milks were obtained from the herds of Sakha Station, Animal Production Research Institute, Agriculture Research Center, Egypt. Milk was analyzed and had following composition : acidity $0.17 \& 0.16$, fat $3.1 \&$ 3.8 specific gravity $27.7 \& 28.3 / 60^{\circ} \mathrm{F}$, lactose $4.2 \& 4.4$ and $\mathrm{pH} 6.61 \& 6.62$ for goat and cow's milk, respectively. Low heat spray dried skim milk powder, of Dutch origin was used.

Bacterial cultures: The used bacterial mixtures in this study are listed in Table 1. All bacterial cultures were maintained by biweekly transfer, incubated at $37^{\circ} \mathrm{C}$, and stored at $4^{\circ} \mathrm{C}$. St. thermophilus TA061 MR$1 \mathrm{C}$, were grown in M17 broth (Terzaghi and Sandine, 1975) containing $0.5 \%$ lactose, while $L$. delbrueckii subsp. bulgaricus MR$1 \mathrm{R}$ was cultured in MRS broth (De-Man et al., 1960) and both were obtained from Chr. Hansen's Laboratory, Copenhagen, Denmark. Lactobacillus acidophilus and Bifidobacterium bifidum were obtained from Laboratorium Wiesby, Niebull, Germany. $B$. bifidum and $L$. acidophilus were separately transferred into sterile skim milk containing $10 \mathrm{~g}$ dextrose and $1 \mathrm{~g}$ yeast extract $/ \mathrm{L}$. $L$. acidophilus was incubated at $37^{\circ} \mathrm{C}$ until coagulation, while Bifidobacterium bifidum was incubated anaerobically at $37^{\circ} \mathrm{C}$ until coagulation. Further activation was achieved by three similar successive transfers in the same medium (Beena and Prasad, 1997).

Making of Labneh: Whole fresh cow's milk and goat's milk were standardized to $3 \%$ milk fat, mixtures of cow and goat' milk (1:1) contained 1, 2 and $3 \%$ milk fat, using fresh skim milk, and all portions of milk were standardized to $14 \%$ TS using skimmed milk powder. All milk samples were heated at $90^{\circ} \mathrm{C}$ for $15 \mathrm{~min}$; homogenized at $250 \mathrm{~kg}$ $\mathrm{cm}^{-2} / 60^{\circ} \mathrm{C}$ cooled to $40^{\circ} \mathrm{C}$ then inoculated with $2 \%$ of the starter cultures as in Table 1. Incubation was carried out at $40^{\circ} \mathrm{C}$ until $\mathrm{pH}$ 4.8. Fermented milks from all treatments were cooled to $10^{\circ} \mathrm{C}$ overnight, mixed and transferred into sterilized cloth bags, hanged in cooling room at $6-8^{\circ} \mathrm{C}$ to allow whey drainage for $12 \mathrm{~h}$. $\mathrm{NaCl}(0.5 \%)$ was added to the bag contents, mixed thoroughly and the resultant Labneh was filled into plastic containers and stored at $6-8^{\circ} \mathrm{C}$ for 21 days. Three replicates of each treatment were made. The Labneh Samples were chemically, microbiologically and organoleptically analyzed as well as the yield of each treatment was determined when fresh and after 7, 14 and 21 days.

Chemical analysis: Titratable acidity (TA $\%$ ), total solids (TS \%) and fat contents were determined according to Ling (1963). Acetaldehyde was determined as given by Lees and Jago (1969). Diacetyl was determined as described by Westerfeld (1945) and lactose content was colorimetrically determined according to the method reported by Nickerson et al., (1976). Tyrosine and tryptophan contents (mg/100) were determined according to Vakaleris and Price (1959). Total volatile free fatty acids (TVFA expressed as ml. $0.1 \mathrm{~N} \mathrm{NaOH} / 10 \mathrm{gm}$ ) were estimated as described by Kosikowski (1982). 


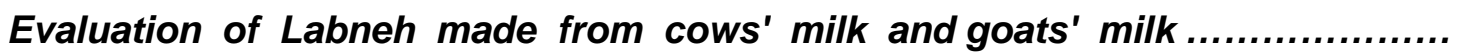

Table 1: The milk and bacterial cultures used in treatments of Labneh

\begin{tabular}{|l|l|l|}
\hline The milk & Type of cultures & Abbreviation \\
\hline $\begin{array}{l}\text { Cow's milk 3\% fat } \\
\text { (control) }\end{array}$ & $\begin{array}{l}4 \% \text { St. thermophilus+ L. delbrueckii subsp. } \\
\text { bulgaricus (traditional) (1:1) }\end{array}$ & C \\
\hline Goat's milk 3\% fat & $\begin{array}{l}4 \% \text { St. thermophilus+ L. delbrueckii subsp. } \\
\text { bulgaricus (traditional) (1:1) }\end{array}$ & G \\
\hline $\begin{array}{l}\text { Cow' milk + Goat's milk } \\
1: 1(3 \% \text { fat, } 1: 1)\end{array}$ & $\begin{array}{l}3 \% \text { St. thermophilus TA061, MR-1C }+ \text { L. } \\
\text { delbrueckii subsp. bulgaricus MR-1R+ (1\% B. } \\
\text { bifidum and L. acidophilus ) (1:1) }\end{array}$ & CG3 \\
\hline $\begin{array}{l}\text { Cow' milk + Goat's milk } \\
1: 1(2 \% \text { fat, } 1: 1)\end{array}$ & $\begin{array}{l}3 \% \text { St. thermophilus TA061, MR-1C + L. } \\
\text { delbrueckii subsp. bulgaricus MR-1R+(1\% B. } \\
\text { bifidum and L. acidophilus (1:1) }\end{array}$ & CG2 \\
\hline $\begin{array}{l}\text { Cow' milk + Goat's milk } \\
1: 1(1 \% \text { fat, } 1: 1)\end{array}$ & $\begin{array}{l}\text { 3\% St thermophilus TA061, MR-1C + L. } \\
\text { delbrueckii subsp. bulgaricus MR-1R+(1\% B. } \\
\text { bifidum and L. acidophilus (1:1) }\end{array}$ & CG1 \\
\hline
\end{tabular}

Microbiological tests: Bifidobacterium bifidum was determined according to Dave and Shah (1996) using modified MRS agar supplemented with $0.05 \%$ L-cystein and $0.3 \%$ lithium chloride. L. acidophilus was enumerated according to Dave and Shah (1996) using MRS-sorbitol agar. Lactic acid bacteria count was determined according to the methods described by the American Public Health Association (1992). Total viable bacterial count was determined according to (APHA, 1978). The count of spore-forming bacteria was determined according to Chalmer (1962). Counts of coliform bacteria were enumerated using the method described by (APHA, 1960). MacConkey agar was prepared as described by Oxoid (1982) for determining Enterobacteriaceae. Counts of psychrotrophic bacteria were estimated by using PCS medium (Bridson, 1990). Potato dextrose agar recommended by the Oxoid (1962) was used for the enumeration of moulds and yeasts. Staphyloeoccus medium No.110 (Difco, 1974) was used to count and detect staphylococci.

Organoleptic evaluations: All Labneh samples were sensory evaluated by eleven of the staff of Sakha Station, Animal
Production Research Lab, according to Ahmed and Ismail (1978). The score points were 60 for flavour, 30 for body \& texture and 10 for appearance which give a total score of 100 points.

Statistical Analysis: The obtained results were statistically analyzed using a software package (SAS, 1991) based on analysis of variance. When $\mathrm{F}$-test was significant, least significant difference (LSD) was calculated according to Duncan (1955) for the comparison between means.

\section{RESULTS AND DISCUSSION Yield and chemical analysis of Labneh:}

Results presented in Table 2 illustrated that yield; TS and F/DM of fresh Labneh was affected by both the milk type and bacterial strain of starter used. Yield, TS and F/DM of fresh and stored Labneh were higher in control $(C)$ than in goats milk Labneh $(G)$. Using starter $[3 \%$ St. thermophilus TA061, MR-1C + L. delbrueckii subsp. bulgaricus MR-1R+(1 \% B. bifidum and L. acidophilus (1:1)] increased yield, TS and F/DM in CG3, CG2 and CG1 treatments despite the low fat in CG2 and CG1 (2 and 1\% fat respectively). CG3 was exhibited the highest yield followed 
by CG2, CG1, C then G treatments, TS and F/DM nearly took the same trend. There were statistical differences in yield, TS and F/DM after the seventh day of storage. These results might be due to the fact that these strains produce exopolysaccharide (EPS) that is tightly associated with the bacterial cell wall (capsular EPS) or liberated into the growth medium (Ropy EPS). Since EPS have viscosity enhancing and stabilizing properties. EPS-producing strains are commonly used to enhance water binding and viscosity in yoghurt and fermented milks and decrease the syneresis defect and improve yields in cheeses (Broadbent et al. 2001). These findings agreed with those reported by Low et al., (1998) and Perry et al., (1997). Genetic studies demonstrated that this effect was due to the MR-1C capsular EPS, and industrial cheese trials confirmed that MR$1 \mathrm{C}$ can resulted a $1.5 \%$ moisture increase in part-skim Mozzarella (Broadbent et al., 2011).

Titratable Acidity (TA): Other chemicals properties of fresh and stored Labneh were summarized in Table 3, TA all treatments increased rapidly till the fourteenth day (1.2$1.3 \%$ ) but it increased slightly during the last week of storage $(1.3-1.42 \%)$, These results correspond with Abou ayana and Ibrahim (2015). This was probably due to the adaptation of bacteria in the middle of storage period. Statistically, $G$ treatment was the highest TA compared to other treatments, this perhaps because of increase the activity of traditional $L A B$ in the goat's milk. Probiotic culture ABT ( $B$. bifidum, $L$. acidophilus and St. thermophilus) has a mild acidic (Kurmann et al., 1992) this might explain our findings. Amer et al., (1998) mentioned that yoghurt (CH-N2) culture produced the greatest TA followed by cheese $(\mathrm{CH}-\mathrm{N} 1)$ culture then ABT culture.

Table 2: The fat, yield and TS in dry matter (F/DM) of fresh and stored Labneh made from cow and goat's milk with EPS lactic acid bacteria (means \pm SD)

\begin{tabular}{|c|c|c|c|c|c|c|}
\hline \multirow[t]{2}{*}{ Items } & \multirow[t]{2}{*}{ Treatments } & \multicolumn{4}{|c|}{ Storage period (day) } & \multirow[t]{2}{*}{ Means \pm SD } \\
\hline & & Fresh & 7 & 14 & 21 & \\
\hline \multirow{5}{*}{ Yield (\%) } & C & $29.0^{\mathrm{a}}$ & $28.4^{\mathrm{a}}$ & $26.5^{c}$ & $24.2^{c}$ & $27.02 \pm 2.01^{\mathrm{D}}$ \\
\hline & G & $28.4^{\mathrm{a}}$ & $27.7^{\mathrm{a}}$ & $25.9^{c}$ & $23.7^{d}$ & $26.40 \pm 1.92^{\mathrm{E}}$ \\
\hline & CG3 & $30.5^{\mathrm{a}}$ & $30.0^{\mathrm{a}}$ & $29.1^{b}$ & $27.5^{d}$ & $29.28 \pm 1.48^{\mathrm{A}}$ \\
\hline & CG2 & $29.7^{\mathrm{a}}$ & $29.2^{\mathrm{a}}$ & $28.1^{c}$ & $26.2^{d}$ & $28.25 \pm 1.38^{\mathrm{B}}$ \\
\hline & CG1 & $28.6^{a}$ & $28.2^{a}$ & $27.0^{\mathrm{c}}$ & $25.1^{\dagger}$ & $27.20 \pm 1.43^{\mathrm{C}}$ \\
\hline \multirow{5}{*}{ TS (\%) } & C & $26.3^{a}$ & $26.2^{a}$ & $26.1^{\mathrm{ab}}$ & $26.0^{d}$ & $26.15 \pm 0.16^{A}$ \\
\hline & $G$ & $26.2^{\mathrm{a}}$ & $26.1^{b}$ & $26.0^{c}$ & $26.0^{c}$ & $26.07 \pm 0.14^{\mathrm{A}}$ \\
\hline & CG3 & $26.5^{\mathrm{a}}$ & $26.4^{\mathrm{c}}$ & $26.3^{e}$ & $26.3^{\mathrm{e}}$ & $26.38 \pm 0.13^{A}$ \\
\hline & CG2 & $26.3^{\mathrm{a}}$ & $26.3^{a}$ & $26.1^{\mathrm{e}}$ & $26.1^{\mathrm{e}}$ & $26.20 \pm 0.15^{A}$ \\
\hline & CG1 & $26.2^{\mathrm{a}}$ & $26.2^{a}$ & $26.0^{e}$ & $26.0^{\mathrm{e}}$ & $26.10 \pm 0.15^{A}$ \\
\hline \multirow{5}{*}{ F/DM (\%) } & C & $38.0^{\mathrm{a}}$ & $38.1^{a}$ & $38.0^{\mathrm{a}}$ & $37.6^{d}$ & $37.92 \pm 0.23^{A}$ \\
\hline & G & $37.7^{\mathrm{a}}$ & $37.7^{\mathrm{a}}$ & $37.5^{\mathrm{c}}$ & $37.2^{d}$ & $37.52 \pm 0.24^{B}$ \\
\hline & CG3 & $37.5^{\mathrm{a}}$ & $37.5^{\mathrm{a}}$ & $37.3^{b}$ & $36.8^{d}$ & $37.28 \pm 0.24^{A}$ \\
\hline & CG2 & $37.0^{\mathrm{a}}$ & $37.0^{\mathrm{a}}$ & $36.8^{b}$ & $36.2^{d}$ & $36.75 \pm 0.37^{\mathrm{C}}$ \\
\hline & CG1 & $36.0^{\mathrm{a}}$ & $36.0^{a}$ & $36.1^{\mathrm{a}}$ & $36.1^{\mathrm{a}}$ & $36.05 \pm 0.12^{\mathrm{D}}$ \\
\hline
\end{tabular}

abcde Letters indicate significant differences between Labneh treatments, ${ }^{A B C D E}$ Letters indicate the means of significant differences between Labneh treatments. C, G, CG3, CG2 and CG1: see table1 
Evaluation of Labneh made from cows' milk and goats' milk ....................

Table 3: Chemical properties of experimental Labneh made from mixtures of cow and goat's milk using EPS lactic acid bacteria (means \pm SD)

\begin{tabular}{|c|c|c|c|c|c|c|}
\hline \multirow[t]{2}{*}{ Properties } & \multirow[t]{2}{*}{ Treatments } & \multicolumn{4}{|c|}{ Storage period (day) } & \multirow[t]{2}{*}{ Means \pm SD } \\
\hline & & Fresh & 7 & 14 & 21 & \\
\hline \multirow{5}{*}{$\begin{array}{l}\text { Acidity } \\
\text { (\%) }\end{array}$} & C & $0.79^{d}$ & $0.99^{c}$ & $1.20^{\mathrm{a}}$ & $1.30^{\mathrm{a}}$ & $1.07 \pm 0.21^{\mathrm{B}}$ \\
\hline & G & $0.81^{d}$ & $0.98^{d}$ & $1.30^{\mathrm{b}}$ & $1.42^{\mathrm{a}}$ & $1.12 \pm 0.25^{\mathrm{A}}$ \\
\hline & CG3 & $0.80^{\mathrm{e}}$ & $0.97^{d}$ & $1.25^{\mathrm{b}}$ & $1.40^{\mathrm{a}}$ & $1.11 \pm 0.23^{\mathrm{A}}$ \\
\hline & CG2 & $0.78^{d}$ & $0.96^{c}$ & $1.20^{\mathrm{b}}$ & $1.30^{\mathrm{a}}$ & $1.06 \pm 0.22^{\mathrm{A}}$ \\
\hline & CG1 & $0.78^{d}$ & $0.97^{\mathrm{c}}$ & $1.20^{\mathrm{b}}$ & $1.30^{\mathrm{a}}$ & $1.06 \pm 0.22^{\mathrm{A}}$ \\
\hline \multirow{5}{*}{$\begin{array}{l}\text { Acetaldehyde } \\
(\mu \mathrm{mol} / 100 \mathrm{~g})\end{array}$} & C & $271^{c}$ & $292^{a}$ & $305^{a}$ & $224^{e}$ & $273.0 \pm 32.9^{\mathrm{E}}$ \\
\hline & $G$ & $275^{c}$ & $298^{a}$ & $309^{a}$ & $237^{e}$ & $279.5 \pm 29.5^{\mathrm{D}}$ \\
\hline & CG3 & $282^{c}$ & $301^{a}$ & $321^{a}$ & $259^{e}$ & $290.7 \pm 67.5^{A}$ \\
\hline & CG2 & $275^{c}$ & $298^{a}$ & $317^{\mathrm{a}}$ & $245^{\mathrm{e}}$ & $283.7 \pm 28.7^{\mathrm{B}}$ \\
\hline & CG1 & $273^{c}$ & $298^{a}$ & $318^{a}$ & $236^{\mathrm{e}}$ & $281.2 \pm 32.7^{\mathrm{C}}$ \\
\hline \multirow{5}{*}{$\begin{array}{l}\text { Diacetyl } \\
(\mu \mathrm{mol} / 100 \mathrm{~g})\end{array}$} & C & $117^{\mathrm{c}}$ & $128^{b}$ & $136^{a}$ & $130^{\mathrm{b}}$ & $127.7 \pm 7.4^{\mathrm{C}}$ \\
\hline & $G$ & $122^{d}$ & $138^{b}$ & $145^{\mathrm{a}}$ & $138^{\mathrm{b}}$ & $135.7 \pm 9.1^{\mathrm{A}}$ \\
\hline & CG3 & $124^{d}$ & $139^{b}$ & $145^{\mathrm{a}}$ & $138^{\mathrm{b}}$ & $136.5 \pm 8.3^{A}$ \\
\hline & CG2 & $122^{d}$ & $137^{b}$ & $141^{a}$ & $136^{b}$ & $134 \pm 20.3^{D}$ \\
\hline & CG1 & $122^{d}$ & $133^{b}$ & $140^{\mathrm{a}}$ & $134^{\mathrm{b}}$ & $132.2 \pm 7.0^{\mathrm{B}}$ \\
\hline \multirow{5}{*}{$\begin{array}{l}\text { Lactose } \\
(\%)\end{array}$} & $C$ & $3.2^{\mathrm{a}}$ & $2.7^{b}$ & $2.3^{c}$ & $2.0^{d}$ & $2.55 \pm 0.49^{A}$ \\
\hline & $\mathrm{G}$ & $3.1^{\mathrm{a}}$ & $2.5^{\mathrm{b}}$ & $2.2^{c}$ & $1.9^{\mathrm{d}}$ & $2.42 \pm 0.49^{\mathrm{A}}$ \\
\hline & CG3 & $3.2^{\mathrm{a}}$ & $2.6^{\mathrm{b}}$ & $2.2^{c}$ & $2.0^{d}$ & $2.50 \pm 0.50^{\mathrm{A}}$ \\
\hline & CG2 & $3.2^{\mathrm{a}}$ & $2.7^{b}$ & $2.2^{c}$ & $2.0^{\mathrm{d}}$ & $2.52 \pm 0.50^{\mathrm{A}}$ \\
\hline & CG1 & $3.2^{\mathrm{a}}$ & $2.7^{b}$ & $2.2^{c}$ & $2.1^{d}$ & $2.53 \pm 0.49^{\mathrm{A}}$ \\
\hline \multirow{5}{*}{$\begin{array}{l}\text { Tyrosine } \\
(\mathrm{mg} / 100 \mathrm{~g})\end{array}$} & C & $16.2^{d}$ & $29.9^{c}$ & $36.2^{b}$ & $42.8^{a}$ & $31.27 \pm 10.5^{B}$ \\
\hline & G & $17.5^{d}$ & $30.2^{c}$ & $37.1^{b}$ & $43.4^{\mathrm{a}}$ & $32.05 \pm 10.3^{A}$ \\
\hline & CG3 & $15.5^{d}$ & $25.2^{c}$ & $33.1^{b}$ & $40.2^{a}$ & $28.50 \pm 9.8^{C}$ \\
\hline & CG2 & $15.5^{d}$ & $25.1^{c}$ & $33.1^{b}$ & $40.3^{a}$ & $28.50 \pm 9.9^{C}$ \\
\hline & CG1 & $15.6^{d}$ & $25.2^{c}$ & $33.1^{b}$ & $40.2^{a}$ & $28.52 \pm 9.8^{C}$ \\
\hline \multirow{5}{*}{$\begin{array}{l}\text { Tryptophan } \\
(\mathrm{mg} / 100 \mathrm{~g})\end{array}$} & C & $97.1^{a}$ & $82.3^{b}$ & $73.2^{c}$ & $55.5^{d}$ & $77.02 \pm 16.11^{\mathrm{B}}$ \\
\hline & G & $98.3^{\mathrm{a}}$ & $82.9^{b}$ & $74.3^{\mathrm{c}}$ & $56.2^{d}$ & $77.92 \pm 16.26^{A}$ \\
\hline & CG3 & $94.1^{\mathrm{a}}$ & $78.8^{b}$ & $71.9^{c}$ & $52.1^{d}$ & $74.22 \pm 16.13^{c}$ \\
\hline & CG2 & $94.2^{\mathrm{a}}$ & $78.8^{b}$ & $71.8^{c}$ & $52.1^{d}$ & $74.22 \pm 16.17^{C}$ \\
\hline & CG1 & $94.2^{\mathrm{a}}$ & $78.8^{b}$ & $71.9^{c}$ & $52.2^{d}$ & $74.27 \pm 16.13^{c}$ \\
\hline \multirow{5}{*}{ TVFA* } & C & $0.33^{f}$ & $0.32^{f}$ & $1.30^{\mathrm{a}}$ & $1.40^{\mathrm{a}}$ & $0.849 \pm 0.54^{\mathrm{A}}$ \\
\hline & CG & $0.46^{f}$ & $0.49^{e}$ & $0.51^{\mathrm{e}}$ & $0.60^{a}$ & $0.515 \pm 0.06^{\mathrm{B}}$ \\
\hline & CG3 & $0.46^{\dagger}$ & $0.48^{\mathrm{e}}$ & $0.51^{d}$ & $0.55^{a}$ & $0.500 \pm 0.04^{\mathrm{CB}}$ \\
\hline & CG2 & $0.45^{\dagger}$ & $0.46^{d}$ & $0.49^{c}$ & $0.52^{a}$ & $0.480 \pm 0.03^{C}$ \\
\hline & CG1 & $0.41^{\dagger}$ & $0.43^{\mathrm{e}}$ & $0.46^{c}$ & $0.49^{a}$ & $0.447 \pm 0.03^{\mathrm{D}}$ \\
\hline
\end{tabular}

${ }^{a b c d e}$ Letters indicate significant differences between Labneh treatments, ${ }^{A B C D E}$ Letters indicate the means of significant differences between Labneh treatments * expressed as $\mathrm{ml} 0.1 \mathrm{NaOH} 10 \mathrm{~g}^{-1} \mathrm{Labneh}^{\mathrm{C}} \mathrm{C}$, G, CG3, CG2 and CG1: see table1 
Acetaldehyde content: Production of flavor compounds (acetaldehyde and diacetyl) depends on the activity and type of starter used and condition of fermentation. Table 3 shows that the content samples of acetaldehyde, influenced by the type of bacterial strains used. Statistically, control Labneh contained the lowest content of acetaldehyde contrary to CG3 treatment that contained the highest acetaldehyde either in fresh or stored samples followed by CG2 then CG1 treatments. These findings might be due to a mixture of bacteria used and the type of milk, although acetaldehyde decreased slightly with the low level of fat. In all samples, acetaldehyde increased with progress the storage period till $14 \mathrm{~d}$ then decreased up to the end of storage period (21 day). Control and all treatments recorded $271 \quad-282 \mu \mathrm{mol} / 100 \mathrm{~g}$ of acetaldehyde at zero time. At the end of storing period, the levels of acetaldehyde were 224, 236, 237, 245, and $259 \mu \mathrm{mol} / 100$ $g$ for C, CG1, G, CG2, and CG3, respectively. These results correspond with Amer et al., (1998) Taha et al., (1997).

Diacetyl content: Concerning diacetyl, data listed in the same table appeared that diacetyl production approximately followed similar trend of acetaldehyde production along the cold storage period. CG3 treatment exhibited the highest diacetyl in both fresh and cold stored Labneh samples but control sample contained the lowest diacetyl. These findings also correspond with Amer et al., (1998) and Taha et al., (1997).

Lactose content: As shown in Table 3, the lactose content clearly reflected the cultures activity; the changes in acidity depend on the changes in lactose which plays a great role. As expected, in G treatment had the lowest lactose content of Labneh compared with the control and other treatments; all fresh samples contained (3.1-3.2\%) lactose at zero time, this quantity gradually decreased along with the storage period to reach between 1.9$2.1 \%$ at the end of cold storage. Lactose content was $3.35 \%$ in fresh Labneh (AbuJdayil and Mohamed, 2002). These results somewhat differ from those reported by Taha et al., (1997).

Tyrosine and tryptophan content: It is clear from the results in Table 3 that tyrosine content in all samples gradually increased as the age of the Labneh produced. Ammar (1995) reported similar results. The tyrosine contents of fresh Labneh ranged from 15.5 to $17.5 \mathrm{mg} / 100 \mathrm{~g}$ and increased at a variable rate to reach 40.2 to $43.4 \mathrm{mg} / 100 \mathrm{~g}$ after 21 days in refrigerator. Noticeable, tyrosine clearly increased in the presence of traditional culture, $G$ treatment had the highest level of tyrosine which might be due to increase the activity of traditional culture in goat's milk more than in cow's milk. These findings confirmed with those of chervaux et al., (2000).

With regard to tryptophan content, it appears that it followed similar trend of tyrosine production, $G$ treatment contained the highest level of tryptophan and it affected by bacterial strain. Traditional bacteria produced the greatest quantities of tryptophan in $\mathrm{G}$ and C $(98.3-97.1 \mathrm{mg} / 100 \mathrm{~g}$ at zero time, respectively) and decreased as storage period to reach $56.2-55.5 \mathrm{mg} / 100 \mathrm{~g}$ at the end of storage period. Increases which associated $G$ and $C$ treatments might be due to effect of traditional culture activity. It is well known that therapeutic bacteria have little proteolytic ability on protein compared with yoghurt culture. These results are similar to those of Amer et al., (1998).

TVFA content: The total volatile fatty acids content were affected by the type of milk, the percent of fat and bacterial of culture (Table 3 ) the control sample had the lowest level of TVFA, contrary $G$ treatment which had the 
highest level. These results might be due to the goat's milk, contains rather higher ratio of volatile fatty acids namely caproic, caprylic and capric acid. This is clearly evident control sample (made of cow's milk) containing the lower level of TVFA. Noteworthy observation, that with decrease the percentage of fat, TVFA clearly decreased $S$. thermophilus and $L$. delbrueckii subsp. bulgaricus, produced higher amount of TVFA than [S. thermophilus TA061, MR-1C, L. delbrueckii subsp. bulgaricus MR-1R and (B. bifidum \& L. acidophilus 1:1)]. This may be due to the ability of traditional bacteria to hydrolyze of protein more than the other bacteria used. On the other hand, TVFA in all control and treatments gradually increased along the storage period to range between 0.52 and $0.1 .4 \mathrm{ml} 0.1 \mathrm{NaOH} / 10 \mathrm{~g}$ at the end of the storage period ( 21 days).

\section{Microbial properties:}

Experimental Labneh samples were microbiologically analyzed during storage; confirmed that counts of total viable count, B. bifidum, L. acidophilus and lactic acid bacteria increased up to the fourteenth day then decreased (Table 4). CG3, CG2 and CG1 treatments exhibited the highest total viable count unlike $C$ that recorded the lowest total viable count. This was the opposite of what was expected, these may be due to the type of milk used, goat's milk is rich of elements and compounds more than cows' milk, bacteria need that elements and compounds to grow well. After 14 day, CG1 treatment had the highest lactic acid bacteria counts (168 cfu $\times 10^{6} / \mathrm{g}$ ) followed by CG3, CG2, G then $C$, meaning that the presence of polysaccharide producing strains encouraged clearly lactic bacteria growth. In connection with $B$. bifidum and $L$. acidophilus counts, they were similar in all treatments. There were no significant differences.
It is necessary to detect the presence of psychrotrophic bacteria that may release heat-resistant proteases and lipases, these enzymes will not be totally inactivated and may give rise to off-flavours (Tamime, 2009), Sahan et al., (2004) reported that the number of psychrotrophic bacteria significantly decreased after 60 days in the samples stored at refrigeration temperature and to a smaller degree decreased in the samples stored at room temperature. Through Table 4 shows that Psychrotrophic bacteria did not detect until 21 day of cold storage. $\mathrm{C}$ had the highest count of Psychrotrophic (12 cfu $\left.\times 10^{2} / \mathrm{g}\right)$ but CG1 contained the lowest number $\left(6 \mathrm{cfu} \times 10^{2} / \mathrm{g}\right)$.

With regard to molds and yeasts, it is clear from Table 4 that molds and yeasts did not appear up to $7 \mathrm{~d}$ and appear after $14 \mathrm{~d}$ then slightly increased to reach between 8$11 \mathrm{cfu} \times 10^{2} / \mathrm{g}$ at the end of cold storage period. $C$ had the highest count of molds and yeasts $\left(11 \mathrm{cfu} \times 10^{2} / \mathrm{g}\right)$. Our results agree with those of Al-Kadamany et al., (2002) who stated that psychrotrophic yeasts increased in stored Labneh at 5 and $15^{\circ} \mathrm{C}$. Results of this work are important to avoid chemical preservatives, Mihyar et al., (1997) confirmed that more than $400 \mathrm{mg} \mathrm{kg}^{-1}$ of sodium benzoate were needed to limit the counts of $S$. cerevisiae, Cryptococcus curvatus, Pichia farinosa, Candida blankii, Debaryomyces hansenii and Trichosporon brassicae to $10^{5} \mathrm{cfu} / \mathrm{g}$ after 14 days at $5^{\circ} \mathrm{C}$; 150 and $300 \mathrm{mg} \mathrm{kg}-1$ were needed for Geotrichum candidum and Trichosporon cutaneum, respectively. However, 100 - > $400 \mathrm{mg}$ of potassium sorbate is needed to inhibit the same yeast in Labneh.

Both of Staph. aureus and coliform group were not detected in Labneh samples (data not shown), this might be due to the efficient heat treatment of milk $\left(95^{\circ} \mathrm{C}\right.$ for $\left.15 \mathrm{~min}\right)$ and high sanitation conditions during manufacture and storage, the obtained results agree with those of Ammara (2000). 
Table 4: Microbiological properties of Labneh manufactured from mixtures of cow and goat's milk with EPS lactic acid bacteria (means \pm SD)

\begin{tabular}{|c|c|c|c|c|c|c|}
\hline \multirow[t]{2}{*}{ Properties } & \multirow[t]{2}{*}{ Treatments } & \multicolumn{4}{|c|}{ Storage period (day) } & \multirow[t]{2}{*}{ Means \pm SD } \\
\hline & & Fresh & 7 & 14 & 21 & \\
\hline $\begin{array}{l}\text { Total viable } \\
\text { count } \\
\left(\text { cfu } \times 10^{6} / \mathrm{g}\right)\end{array}$ & $\begin{array}{l}\text { C } \\
G \\
C G 3 \\
C G 2 \\
C G 1\end{array}$ & $\begin{array}{l}159^{d} \\
165^{d} \\
171^{d} \\
170^{d} \\
171^{d}\end{array}$ & $\begin{array}{l}175^{\mathrm{a}} \\
181^{\mathrm{a}} \\
183^{\mathrm{a}} \\
182^{\mathrm{b}} \\
182^{\mathrm{a}}\end{array}$ & $\begin{array}{l}182^{\mathrm{a}} \\
187^{\mathrm{a}} \\
189^{\mathrm{a}} \\
188^{\mathrm{a}} \\
187^{\mathrm{a}}\end{array}$ & $\begin{array}{l}155^{d} \\
159^{d} \\
162^{e} \\
162^{f} \\
160^{f}\end{array}$ & $\begin{array}{l}167 \pm 11.94^{\mathrm{C}} \\
173 \pm 12.23^{\mathrm{B}} \\
176 \pm 11.25^{\mathrm{A}} \\
175 \pm 10.89^{\mathrm{A}} \\
175 \pm 11.19^{\mathrm{A}}\end{array}$ \\
\hline $\begin{array}{l}\text { B. bifidum } \\
\left.\text { (cfu } \times 10^{6} / \mathrm{g}\right)\end{array}$ & $\begin{array}{l}\text { C } \\
G \\
C G 3 \\
C G 2 \\
C G 1\end{array}$ & $\begin{array}{l}- \\
- \\
22^{d} \\
23^{d} \\
22^{d}\end{array}$ & $\begin{array}{l}- \\
- \\
26^{\mathrm{a}} \\
25^{\mathrm{b}} \\
25^{\mathrm{a}}\end{array}$ & $\begin{array}{l}- \\
- \\
27^{\mathrm{a}} \\
27^{\mathrm{a}} \\
25^{\mathrm{a}}\end{array}$ & $\begin{array}{l}- \\
- \\
21^{d} \\
21^{f} \\
22^{d}\end{array}$ & $\begin{array}{l}- \\
- \\
24 \pm 2.93^{\mathrm{A}} \\
24 \pm 2.62^{\mathrm{A}} \\
23 \pm 1.93^{\mathrm{A}}\end{array}$ \\
\hline $\begin{array}{l}\text { L. acidophilus } \\
\left.\text { (cfu } \times 10^{6} / \mathrm{g}\right)\end{array}$ & $\begin{array}{l}\mathrm{C} \\
\mathrm{G} \\
\mathrm{CG} 3 \\
\mathrm{CG} 2 \\
\mathrm{CG} 1\end{array}$ & $\begin{array}{l}- \\
- \\
24^{d} \\
25^{c} \\
25^{b}\end{array}$ & $\begin{array}{l}- \\
- \\
27^{\mathrm{a}} \\
28^{\mathrm{a}} \\
26^{\mathrm{a}}\end{array}$ & $\begin{array}{l}- \\
- \\
28^{a} \\
28^{a} \\
26^{a}\end{array}$ & $\begin{array}{l}- \\
23^{d} \\
22^{d} \\
23^{d}\end{array}$ & $\begin{array}{l}- \\
- \\
25 \pm 2.44^{\mathrm{A}} \\
25 \pm 2.87^{\mathrm{A}} \\
25 \pm 1.69^{\mathrm{A}}\end{array}$ \\
\hline $\begin{array}{l}\text { Lactic acid } \\
\text { bacteria } \\
\left(\text { cfu } \times 10^{6} / \mathrm{g}\right)\end{array}$ & $\begin{array}{l}\mathrm{C} \\
\mathrm{G} \\
\mathrm{CG} 3 \\
\mathrm{CG} 2 \\
\mathrm{CG} 1\end{array}$ & $\begin{array}{l}135 f \\
141 \mathrm{e} \\
143 \mathrm{e} \\
143 \mathrm{e} \\
144 \mathrm{e}\end{array}$ & $\begin{array}{l}157 a \\
163 a \\
165 a \\
165 a \\
167 a\end{array}$ & $\begin{array}{l}161 a \\
164 a \\
166 a \\
165 a \\
168 a\end{array}$ & $\begin{array}{l}149 d \\
153 c \\
154 c \\
154 c \\
154 c\end{array}$ & $\begin{array}{c}150 \pm 10.68^{\mathrm{C}} \\
155 \pm 10.24^{\mathrm{B}} \\
157 \pm 10.06^{\mathrm{AB}} \\
156 \pm 9.80^{\mathrm{AB}} \\
157 \pm 10.15^{\mathrm{A}}\end{array}$ \\
\hline $\begin{array}{l}\text { Mold \& Yeast } \\
\left(\mathrm{cfu} \times 10^{2} / \mathrm{g}\right)\end{array}$ & $\begin{array}{l}\mathrm{C} \\
\mathrm{G} \\
\mathrm{CG} 3 \\
\mathrm{CG} 2 \\
\mathrm{CG} 1\end{array}$ & $\begin{array}{l}\text { ND } \\
\text { ND } \\
\text { ND } \\
\text { ND } \\
\text { ND }\end{array}$ & $\begin{array}{l}\text { ND } \\
\text { ND } \\
\text { ND } \\
\text { ND } \\
\text { ND }\end{array}$ & $\begin{array}{l}7 c \\
6 d \\
5 e \\
6 d \\
5 e\end{array}$ & $\begin{array}{l}11 a \\
9 a \\
8 b \\
8 b \\
9 a\end{array}$ & $\begin{array}{l}4.50 \pm 5.10^{A} \\
3.75 \pm 4.23^{A B} \\
3.25 \pm 3.73^{B} \\
3.50 \pm 3.89^{A B} \\
3.50 \pm 4.10^{A B}\end{array}$ \\
\hline $\begin{array}{l}\text { Psychrotrophic } \\
\text { bacteria } \\
\left(\mathrm{cfu} \times 10^{2} / \mathrm{g}\right)\end{array}$ & $\begin{array}{l}\mathrm{C} \\
\mathrm{G} \\
\mathrm{CG} 3 \\
\mathrm{CG} 2 \\
\mathrm{CG} 1\end{array}$ & $\begin{array}{l}\text { ND } \\
\text { ND } \\
\text { ND } \\
\text { ND } \\
\text { ND }\end{array}$ & $\begin{array}{l}\text { ND } \\
\text { ND } \\
\text { ND } \\
\text { ND } \\
\text { ND }\end{array}$ & $\begin{array}{l}\text { ND } \\
\text { ND } \\
\text { ND } \\
\text { ND } \\
\text { ND }\end{array}$ & $\begin{array}{l}12 a \\
9 a \\
7 a \\
7 a \\
6 a\end{array}$ & $\begin{array}{l}3.00 \pm 5.58^{A} \\
2.37 \pm 4.47^{A B} \\
1.75 \pm 3.28^{B} \\
1.75 \pm 3.28^{B} \\
1.50 \pm 2.83^{B}\end{array}$ \\
\hline
\end{tabular}

${ }^{\text {abcde }}$ Letters indicate significant differences between Labneh treatments, ${ }^{A B C D E}$ Letters indicate the means of significant differences between Labneh treatments ND: not detected, -: the culture starter is free of this strain. C, G, CG3, CG2 and CG1: see table1

Aerobic spore forming bacteria were not be detected in all of examined treatments whether fresh or after storage.

\section{Organoleptic properties:}

Data listed in Table 5. indicated that CG1 gained the highest scoring points followed 
by CG2, CG3, $C$ then $G$ whether in fresh or after 7,14 and 21 days of the cold storage. These results explain the effect of bacterial strains producing EPS on properties of Labneh. EPS-producing (EPS $\left.{ }^{+}\right)$LAB are commonly used as starter cultures for yogurt manufacture because EPS improves the viscosity and texture of yogurt and decreases its susceptibility to syneresis (loss of whey from the curd) (Kang and Cottrell,1979 and Van den Berg et al.,1995). Because EPS have viscosity enhancing and stabilizing properties, exopolysaccharide- producing (EPS) starter cultures are commonly used to enhance water binding and viscosity in yogurt and fermented milks as well as thickness. Low fat Mozzarella cheese made with an EPS starter pair, Streptococcus thermophilus MR-1C and Lactobacillus delbrueckii subsp. bulgaricus MR-1R, contained significantly more moisture and had better melt properties than cheese made with a control starter pair (Broadbent et al.2011). These results are in agreement with those reported by Abou ayana and Ibrahim (2015).

Table 5: organoleptic evaluation of Labneh made from mixtures of cow and goat's milk with exopolysaccharide bacteria cultures (means \pm SD)

\begin{tabular}{|c|c|c|c|c|c|c|}
\hline \multirow[t]{2}{*}{ Properties } & \multirow[t]{2}{*}{ Treatments } & \multicolumn{4}{|c|}{ Storage period (day) } & \multirow[t]{2}{*}{ Means \pm SD } \\
\hline & & Fresh & 7 & 14 & 21 & \\
\hline \multirow{5}{*}{$\begin{array}{l}\text { Flavor } \\
(60)\end{array}$} & C & $55^{\mathrm{a}}$ & $55^{\mathrm{a}}$ & $54^{\mathrm{b}}$ & $53^{c}$ & $54.50 \pm 1.60^{A}$ \\
\hline & $G$ & $53^{\mathrm{a}}$ & $51^{b}$ & $50^{c}$ & $48^{d}$ & $50.50 \pm 2.20^{C}$ \\
\hline & CG3 & $56^{\mathrm{a}}$ & $54^{\mathrm{b}}$ & $52^{d}$ & $50^{\mathrm{e}}$ & $53.00 \pm 2.62^{\mathrm{B}}$ \\
\hline & CG2 & $58^{\mathrm{a}}$ & $56^{\mathrm{a}}$ & $54^{\mathrm{C}}$ & $52^{d}$ & $55.00 \pm 2.62^{A}$ \\
\hline & CG1 & $58^{a}$ & $57^{\mathrm{a}}$ & $55^{\mathrm{c}}$ & $54^{\mathrm{C}}$ & $56.00 \pm 2.00^{A}$ \\
\hline \multirow{5}{*}{$\begin{array}{l}\text { Body \& } \\
\text { Texture (30) }\end{array}$} & C & $26^{a}$ & $24^{c}$ & $21^{e}$ & $20^{\mathrm{e}}$ & $22.75 \pm 2.76^{\mathrm{B}}$ \\
\hline & $G$ & $26^{\mathrm{a}}$ & $24^{\mathrm{C}}$ & $23^{d}$ & $22^{e}$ & $23.75 \pm 1.91^{\mathrm{B}}$ \\
\hline & CG3 & $27^{\mathrm{a}}$ & $27^{\mathrm{a}}$ & $25^{\mathrm{c}}$ & $25^{\mathrm{c}}$ & $26.00 \pm 1.51^{\mathrm{A}}$ \\
\hline & CG2 & $27^{\mathrm{a}}$ & $26^{\mathrm{a}}$ & $24^{c}$ & $24^{c}$ & $25.25 \pm 1.75^{\mathrm{A}}$ \\
\hline & CG1 & $28^{a}$ & $26^{\mathrm{c}}$ & $25^{d}$ & $25^{d}$ & $26.00 \pm 1.69^{A}$ \\
\hline \multirow{5}{*}{$\begin{array}{l}\text { Appearance } \\
\text { (10) }\end{array}$} & C & $8^{a}$ & $8^{a}$ & $7^{b}$ & $6^{c}$ & $7.25 \pm 1.39^{A}$ \\
\hline & $G$ & $8^{a}$ & $8^{a}$ & $7^{b}$ & $6^{c}$ & $7.25 \pm 1.39^{\mathrm{A}}$ \\
\hline & CG3 & $8^{a}$ & $8^{a}$ & $7^{b}$ & $7^{b}$ & $7.50 \pm 1.19^{A}$ \\
\hline & CG2 & $9^{a}$ & $9^{a}$ & $8^{b}$ & $8^{b}$ & $8.50 \pm 1.19^{A}$ \\
\hline & CG1 & $9^{a}$ & $9^{a}$ & $8^{b}$ & $8^{b}$ & $8.50 \pm 1.19^{A}$ \\
\hline \multirow{5}{*}{$\begin{array}{l}\text { Total } \\
(100)\end{array}$} & C & $90^{\mathrm{a}}$ & $88^{a}$ & $82^{c}$ & $79^{d}$ & $84.75 \pm 2.23^{C}$ \\
\hline & $G$ & $87^{a}$ & $84^{a}$ & $80^{c}$ & $76^{d}$ & $81.75 \pm 1.99^{\mathrm{D}}$ \\
\hline & CG3 & $91^{\mathrm{a}}$ & $89^{a}$ & $84^{c}$ & $82^{\mathrm{e}}$ & $86.50 \pm 2.11^{B}$ \\
\hline & CG2 & $94^{a}$ & $91^{a}$ & $86^{c}$ & $84^{d}$ & $88.75 \pm 2.34^{\mathrm{A}}$ \\
\hline & $\mathrm{CG}_{1}$ & $94^{\mathrm{a}}$ & $91^{a}$ & $87^{c}$ & $86^{c}$ & $89.50 \pm 2.25^{\mathrm{A}}$ \\
\hline
\end{tabular}

abcde Letters indicate significant differences between Labneh treatments, ${ }^{\mathrm{ABCDE}}$ Letters indicate the means of significant differences between Labneh treatments. C, G, CG3, CG2 and CG1: see table1 
On the other hand, an negative correlation between the percentage of goats' milk fat and sensory evaluation of flavor of Labneh was observed. Although goats' milk fat improved the body, texture and appearance of Labneh but the flavor of G3 samples had lowest points 53 out of 60 in fresh and decreased to reach 48 after 21 days of storage and was not accepted and rejected by most of the panelists. This could be attributed to free fatty acids especially Caproic, caprylic and capric (totaling of $15 \%$ of goat milk fat). These findings agree with those reported by Abou Ayana and Gamal El Deen (2011)

\section{CONCLUSIONS}

Using bacterial strains producing EPS is recommended to enhance flavor and rheological properties of Labneh made from mixtures of cow's and goat's milk as well as increase of yield.

\section{REFERENCES}

Abou Ayana, I.A.A. and Amal Elsady Ibrahim (2015). Attributes of Low-Fat Yogurt and Kareish Cheese Made Using Exopolysaccharides Producing Lactic Acid Bacteria. American Journal of Food Technology, 10: 48-57.

Abou Ayana, I. A. A. and A. A. Gamal El Deen (2011). Improvement of the Properties of Goat's Milk Labneh using some Aromatic and Vegetable Oils. Int. J Dairy Science, 6: 112-123.

Abu-Jdayil, B. and H. Mohameed (2002). Experimental and modelling studies of the flow properties of concentrated yogurt as affected by the storage time. J. Food Eng., 52: 359-365.

Ahmed, N. S. and A. A. Ismail (1978). Enrichment of zabadi with whey proteins. J. Dairy Res., 45: 119-121.

Al-Kadamany, E., I. Toufeili, M. Khattar, Y. Abou-Jawdeh, S. Harakeh and $T$. Haddad (2002). Determination of shelf life of concentrated yogurt (Labneh) produced by in-bag straining of set yogurt using hazard analysis. J. Dairy Sci., 85: 1023-1030.

Amer, S. N., E. S. Girgis, S. H. Taha and S. H. Abd-El-Moeety (1998). Effect of milk total solids and type of starter on quality of Labneh. Egypt. J. Dairy Sci., 25: 179192.

American Public Health Association (1992). Standard methods for the examination of dairy products. Amer. Publ. Health Assoc. Inc. $12^{\text {th }}$ ed., New York, USA.

Ammar, El-Tahra, M. A. (1995). Biochemical characteristics and elctrophoretic patterns of Edam cheese made from cow's, goat's milk and some mixtures of them during ripening period. J. Agric. Sci. Mansoura Univ., 20: 3425-3439.

Ammara, I. E. M. (2000). Studied on use of bifidobacteria in manufacture some dairy products. M.Sc. Thesis, Faculty of Agriculture, Ain Shams University, Cairo, Egypt.

APHA. (1960). Standard Methods for the Examination of Milk and Dairy Products. American Public Health Association.

APHA. (1978). Standard Methods for the Examination of Dairy Products 1970. American Public Health Association.

Beena, A. and V. Prasad (1997). Effect of yoghurt and bifidus yoghurt fortified with skim milk powder, condensed whey and lactose- hydrolyzed condensed whey on serum cholesterol and triacylglycerol levels in rats. J. Dairy Res. 64: 453-457.

Bridson, E.Y. (1990). The Oxoid Manual. $6^{\text {th }}$ Edn., Unipath Ltd., Basingstoke, UK.

Broadbent, J. R., H. Cai, R. L. Larsen, J. E. Hughes, D. L. Welker and V. G. De Carvalho (2011). Genetic diversity in proteolytic enzymes and amino acid metabolism among $L$. helveticus strains. J. Dairy Sci. 94 4313-4328.

Broadbent, J. R., J. Donald, A. McMahon, J. Craig, D. Oberg and D. L. Welker (2001). 
Use of exopolysaccharide-producing cultures to improve the functionality of low fat cheese. Int. Dairy J, Vol. 11, 116 , 433-439

Chalmer, C. H. (1962). Bacteria in Relation to the Milk Supplies. $4^{\text {th }}$ Edn., Edward Arnold Ltd., London.

Chervaux, C., S. D. Erlich and E. Maguin (2000). Physiological study of Lactobacillus delbrueckii subsp. bulgaricus strains in a novel Chemically Defined Medium. Appl. Environ. Microbiol., 66:5306-5311.

Dave, R. I. and N. P. Shah (1996). Evaluation of media for selective enumeration of Streptococcus thermophilus, Lactobacillus delbrueckii sp.bulgaricus, Lactobacillus bifidobacteria. J. Dairy Sci., acidophilus and

De-Man J., Rogosa, M. and Sharpe, M. E. (1960): A medium for the cultivation of lactobacilli. J. Appl. Bacteriol. 23:130135.

DIFCO, (1974). Difco Manual of Dehydrate Culture Media and Reagents for Microbiological and Clinical Laboratory Procedures. Difco Laboratories, Michigan, USA.

Duncan, D. B. (1955). Multiple Range and Multiple F-test. Biometrics, 11:1- 42.

FAO, 2011. Statistics. FAO, Geneva.

Haenlein, G. F.W. (2004). Goat milk in human nutrition. Small Rumin. Res., 51: 155-163. Health Association Inc., Broadway, New York.

Kang, K. S. and I. W. Cottrell (1979). Polysaccharides. In Microbial technology: microbial processes, eds Peppler H. J., Perlman D. (Academic Press, Inc. New York, N.Y), $2^{\text {nd }}$ ed. 1:417-481.

Kosikowski, F.V. (1982). Cheese and Fermented Milk Foods. $2^{\text {nd }}$ Edn., FV Kosikowski and Associates, Brooktondale, New York.

Kurmann, J. A., J. L. Rasic and M. Kroger (1992). Encyclopedia of Fermented
Fresh Milk Products: An International Inventory of Fermented Milk, Cream, Buttermilk, Whey and Related Products. 1st Edn., E. van Nostrand Reinhold, New York.

Lees, G. J. and G. R. Jago (1969). Methods for the estimation of acetaldehyde in cultured dairy products. Aust. J. Dairy Technol., 24:181-184.

Ling, E. R., (1963). Text Book of Dairy Chemistry: Practical. $3^{\text {rd }}$ Edn. Vol. 2, Chapman and Hall Ltd., London.

Low, D., J. A. Ahlgren, D. Horne, D. J. McMahon, C. J. Oberg and J. R. Broadbent (1998). Role of St. thermophilus MR-1C capsular exopolysaccharide in cheese moisture retention. Appl Environ Microbiol. 64 2147-51

Mihyar, G.F., M.I. Yamani and A.K. Al-Saed (1997). Resistance of yeast flora of labaneh to potassium sorbate and sodium benzoate. J. Dairy Sci., 80: 23042309.

Nickerson, T.A., I. F. Vujicic and A.Y. Lin (1976). Colorimetric estimation of lactose and its hydrolytic products. J. Dairy Sci., 59: 386-390.

Oxoid, (1962). The Oxoid Manual of Culture Media. $2^{\text {nd }}$ Edn., Oxoid Ltd., London.

Oxoid, (1982). The Oxoid Manual of Culture Media, Ingredients and Other Laboratory Services. $5^{\text {th }}$ Edn., Oxoid Ltd., London.

Park, Y.W., M. Juarez, M. Ramos and G. F. W. Haenlein (2007). Physico-chemical characteristics of goat and sheep milk. Small Rumin. Res., 68: 88-113.

Perry, D. B., D. J. McMahon and C. J. Oberg (1997): Effect of exopolysaccharide producing cultures on moisture retention in low-fat mozzarella cheese. J. Dairy Sci. 80:799-805.

Sahan, N., I. Var, D. Say and E. Aksan (2004). Microbiological properties of Labneh (concentrated yoghurt) stored without vegetable oil at room or 
refrigeration temperatures. Acta Alimentaria, 33: 175-182.

SAS (1991). SAS User's guide: statistics. SAS Inst, Inc, Cary, NC.

Sutherland, I. W. (1972). Bacterial exopolysaccharides. Adv. Microbiol. Physiol. 8, 143-213.

Sutherland, I. W. (1990). Biotechnology of Microbial Exopolysaccharides. Cambridge University Press, Cambridge, UK.

Taha, S. H., E. S. Girgis, S. N. Amer and S. H. Abd-El-Moeety (1997). Effect of milk fat substitution with vegetable oils on the quality attributes of Labneh. Egyptian J. Dairy Sci., 25: 193-203.

Tamime, A. Y. and R. K. Robinson (1999). Yoghurt: Science and Technology. $2^{\text {nd }}$ Ed., Woodhead Publishing, Cambridge, pp: 619.

Tamime, A.Y. (2009). Milk Processing and Quality Management. Blackwell Pubilshing, New York.

Tamime, A.Y., G. Davies, A. S. Chehade and H. A. Mahdi (1991). The effect of processing temperatures on the quality of Labneh made by ultrafiltration. Int. J. Dairy Technol., 44: 99-103.

Terzaghi B. E. and W. E. Sandine (1975). Improved medium for lactic streptococci and their bacteriophages. Appl. Microbiol. 29:807-813.

Vakaleris, D.G. and Price, W.V. (1959). A rapid spectrophotometric method for measuring cheese ripening. J. Dairy Sci., 42: 264-276.

Van den Berg, D. J. C., G. W. Robijn, A. C. Janssen, M. L. F. Giuseppin, R. Vreeker, J. P. Kamerling, J. F. G. Vliegenthart, A. M. Ledeboer and C. T. Verrips (1995). Production of a novel extracellular polysaccharide by Lactobacillus sake $0-1$ and characterization of the polysaccharide. Appl. Environ. Microbiol. 61:2840-2844.

Westerfeld, W. W. (1945). A colorimetric determination of blood acetoin. J. Biol. Chem., 161: 495-499. 
تقييم اللّبنة المُصَنْعة من خليط من لبن الماعز واللبن البقرى باستخدام البكتريا

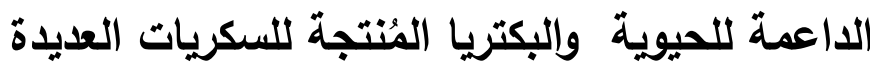

\author{
عبد الستار محمد طلبة جبر \\ قسم بحوث تكنولوجيا الألبان ، معهز بحوث تكونولوجيا الأغذية -مركز البحوث الزراعية -الجيزة ،مصر

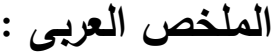

السكريات الميكروبية العديدة هي مُثتبتات حيوية يمكن ان تُضاف إلى العديد من المنتجات الغذائية، حيث تزيد

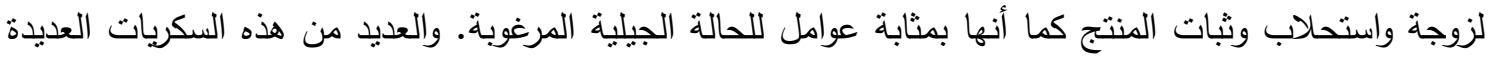

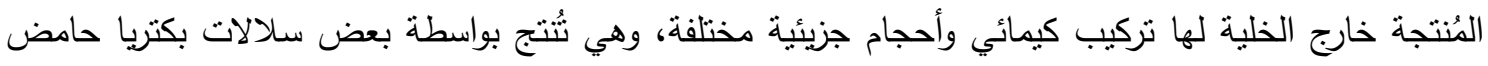
اللاكتيك.

الهدف من هذا البحث هو تقييم اللبنة المصنعه من خليط من لبن الماعز واللبن البقرى باستخدام بكتريا

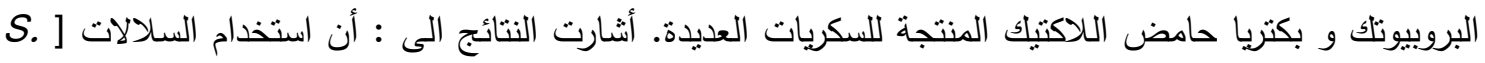
thermophilus TA061, MR-1C + L. delbrueckii subsp. bulgaricus MR-1R+ (B. bifidum

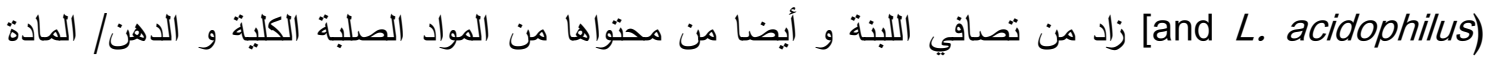

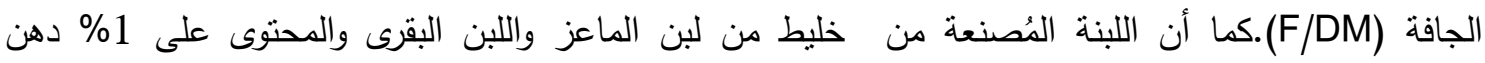

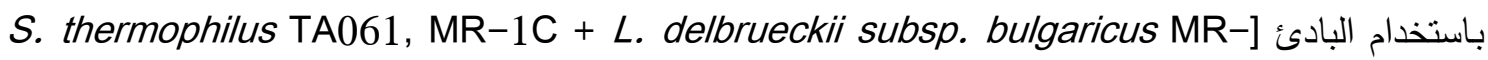
[1R+ (B. bifidum and L. acidophilus 1:1] حصلت على أعلى تقييم حسى على عكس اللبنة المُصنعة من لبن الماعز 3\% دهن و المّصنعة باستخدام البادئ النقليدي. 
